\title{
Effect of Traditional Dried Starter Culture on Morphological, Chemical and Physicochemical Properties of Sweet Fermented Glutinous Rice Products
}

\author{
Vipa Surojanametakul ${ }^{1}$, Wanchai Panthavee ${ }^{1}$, Prajongwate Satmalee ${ }^{1}$, Naraporn Phomkaivon ${ }^{1}$ \\ $\&$ Tadashi Yoshihashi ${ }^{2}$ \\ ${ }^{1}$ Institute of Food Research and Product Development, Kasetsart University, Bangkok, Thailand \\ ${ }^{2}$ Japan International Research Center for Agricultural Sciences (JIRCAS), Tsukuba, Japan \\ Correspondence: Vipa Surojanametakul, Institute of Food Research and Product Development, Kasetsart \\ University, Bangkok 10900, Thailand. Tel: 660-294-286-2935. E-mail: ifrvis@ku.ac.th
}

\author{
Received: February 10, $2019 \quad$ Accepted: March 20, $2019 \quad$ Online Published: May 15, 2019 \\ doi:10.5539/jas.v11n6p43 URL: https://doi.org/10.5539/jas.v11n6p43
}

\begin{abstract}
Sweet glutinous rice products or khao-mak in Thai were prepared by fermenting cooked glutinous rice (RD6 variety) using traditional starter cultures from Samut Sakhon (SSK) and Pathum Thani (PTT) Provinces at room temperature $\left(28 \pm 2{ }^{\circ} \mathrm{C}\right)$ for 3 days. Amylolytic activities of microbial excisting in the traditional starter cultures were tested. Meanwhile, types and amounts of microbial growth in fermented rice products were investigated. Both traditional dried starter cultures showed strong amylolytic activity after inoculation for 2 and 3 days in starch agar. Microbiological profiles of rice fermentation were varied in total plate count, yeast and molds over the fermentation period. Different starter cultures resulted in a wide variation of end products with diverse chemical, microbiological and morphology properties; however those changes exhibited similar trends in all treatments. As fermentation time increased, protein content remained unchanged while total soluble solids, $\mathrm{pH}$, acidity, sugar and alcohol content markedly increased compared with unfermented cooked rice. PTT showed products with higher acidity and alcohol content $(0.50 \%, 2.58 \%)$ than SSK $(0.31 \%, 1.85 \%)$. Morphological examination of rice grains revealed that microbial growth started from the outer surface and then moved inside the rice grains with greater corrosion was observed as fermentation time increased. Pasting and gelatinization properties of the rice flour were also strongly affected by fermentation.
\end{abstract}

Keywords: rice, rice products, sweet glutinous rice, traditional starter culture

\section{Introduction}

Historically, traditional fermented foods have played a very important role in many countries including Thailand, either as main dishes or as condiments. Nowadays, the younger generation has become less interested in these products, which have good impacts on health, due to the influence of Western style diets. Among fermented food products, sweet fermented glutinous rice known as "Amasake" in Japanese or "khao-mak" in Thai is popularly consumed as a sweet dessert or as a seasoning that provides both sweetness and an appetizing aroma of alcohol and acids (Tanasupawat \& Komagata, 1995). Campbell-Platt (1994) reported that the fermentation process had several inherent benefits by altering the functional properties of starch embedded in the rice. Generally, final product quality is strongly influenced by the production processes. Khao-mak is a probiotic product (De Llanos, Querol, Pemán, Gobernato, \& Fernández-Espinar, 2006) containing viable helpful microorganisms (mold and yeast) which confer health benefits when consumed in adequate amounts (Manosroi, Ruksiriwanich, Kietthanakorn, Manosroi, \& Manosroi, 2011). Khao-mak is also used as a dietary supplement to increase and maintain a healthy gut flora by providing food for bacteria (Tongyai, Riebroy, Maneerat, Siriwong, \& Chulakarungka, 2012).

Traditionally, khao-mak is usually prepared by washing whole grains of glutinous rice and steeping them $3 \mathrm{~h}$ to allow the water to diffuse into the rice kernels; however, some components leach out (Chen, Lu, \& Lii, 1999; Phothiset \& Charoenrein, 2007). The soaked rice grains are cooked using steam to gelatinize the starch, and then cooled to room temperature prior to brewing with a starter cake containing mold, yeast and bacteria inoculated in rice flour mixed with herbs (Limtong, Sintara, Suwanarit, \& Lotong, 2002). The mixture of cooked rice and 
starter is then fermented at room temperature for 2 or 3 days to obtain the desired khao-mak characteristics as lumps of cooked glutinous rice with soft texture, pale white color, succulent grains, and acidic sweet taste with little alcohol flavor (Wongpiyachon, 1995). Longer fermentation is not acceptable because it creates off-flavors due to excessive alcohol and acid content (Tochampa, Jittrepotch, Kongbangkerd, Kraboun, \& Rojsuntornkitti, 2011). Generally, product quality characteristics vary considerably from place to place depending on many factors including traditional starter cultures, environmental conditions and fermentation times. Although khao-mak has been fermented and consumed since the olden days, scientific data concerning changes in rice morphology and properties during fermentation remain limited. Therefore, this research investigated the changes in rice grain morphology and chemical composition as well as physicochemical properties of rice flour during fermentation. Increased knowledge through collecting process practices monitoring data can be used to improve the quality of khao-mak as a healthcare food choice for consumers.

\section{Method}

\subsection{Materials}

Glutinous rice, RD6 variety from Nong Khai, a province in northeastern Thailand, was used as raw material for sweet fermented glutinous rice or khao-mak production. Traditional dried starter cultures, or rice cake starter, were collected from Samut Sakhon (SSK) and Pathum Thani (PTT) provinces in the central part of Thailand.

\subsection{Khao-Mak Preparation}

The method for preparing khao-mak in the laboratory was adapted from a local manufacturer, with some modifications. Rice kernels were washed and soaked in water for $3 \mathrm{~h}$. After draining, the soaked rice was steamed for $25 \mathrm{~min}$, then cooled for $1 \mathrm{~h}$ at room temperature, and water was added to make the cooked rice less sticky. Cooked rice was mixed with starter culture powder $(0.14 \% \mathrm{w} / \mathrm{w}$ of sample), packed in plastic bags (200 $\mathrm{g} /$ each) and incubated at $30^{\circ} \mathrm{C}$ for up to 3 days to induce fermentation. The fermented products were randomly withdrawn from the incubator every day. One part of the sample was blended and kept at $-20{ }^{\circ} \mathrm{C}$ for composition analysis, while the other was freeze-dried and used for morphological and physicochemical analyses. Unfermented steamed glutinous rice added with water was used as a control.

\subsection{Microbiological Characteristic Determination}

Amylolytic activity of microbes in the starter cultures was tested following the method of Laloknam, Sirisopana, Attaphinyo, Poohuarai, \& Phornphisutthimas (2009). In addition cooked glutinous rice mixed with starter culture was examined for total microorganisms, mold and yeast content during the 1-3 day fermentation according to BAM (Bacteriological Analytical Manual) (1998). Total plate count were performed using plate count agar (PCA) while mold and yeast used dichloran 18\% glycerol (DG18) agar, then isolate individual colonies on PDA.

\subsection{Chemical Composition Analysis}

Moisture, protein, titratable acidity (as \%lactic acid) and alcohol content of the control sample and khao-mak after fermentation for 1-3 days were determined by the AOAC (Association of Official Analytical Chemists) (2006) standard method. The $\mathrm{pH}$ value of samples was measured using a $\mathrm{pH}$ meter (Docu- $\mathrm{pH}_{\mathrm{Meter}}$; Sartorius, Goettingen, Germany). Glucose, maltose and total sugar were analyzed using an Agilent 1100 series high-performance liquid chromatography (HPLC) system (Agilent Technologies, Santa Clara, CA, USA) following the AOAC method (2006).

\subsection{Grain Morphology}

Freeze-dried sample grains, unfermented and fermented, were placed in a vacuum evaporator attached to an aluminum stub with carbon tape and sputter-coated with gold (Ion Coater IB-2, Eiko, Japan). Samples were characterized by a scanning electron microscope (SEM, JEOL JSM-5600 LV, Japan) operating at an accelerating voltage of $10 \mathrm{kV}$.

\subsection{Pasting Properties}

Pasting properties of all flours obtained from freeze dried grains (unfermented and fermented) were determined using a Rapid Visco Analyzer (RVA-super 3, Newport Scientific, New South Wales, Australia) with standard profile program following the International Approved Methods of Analysis [AACC] (2000) Method 61-02.01 observed parameters were peak viscosity, trough, final viscosity, breakdown and setback.

\subsection{Thermal Properties}

Gelatinization characteristics were determined using a differential scanning calorimeter (DSC) (Pyris ${ }^{\mathrm{TM}}$ Diamond DSC; PerkinElmer, Waltham MA, USA) calibrated with indium. An empty stainless steel pan was used as a 
reference. Flour suspensions were prepared at 70\% moisture content, then hermetically sealed in a stainless steel pan and allowed to stand for $2 \mathrm{~h}$ at room temperature to equilibrate. Scanning temperature range and heating rate for melting point analysis were $30{ }^{\circ} \mathrm{C}$ to $140^{\circ} \mathrm{C}$ at a rate of $10^{\circ} \mathrm{C} / \mathrm{min}$, respectively. From the DSC curve, onset temperature $\left(\mathrm{T}_{\mathrm{o}}\right)$, peak temperature $\left(\mathrm{T}_{\mathrm{p}}\right)$, conclusion temperature $\left(\mathrm{T}_{\mathrm{c}}\right)$, temperature range $\left(\mathrm{T}_{\mathrm{o}}-\mathrm{T}_{\mathrm{c}}\right)$ and transition enthalpy $(\Delta \mathrm{H})$ were evaluated.

\subsection{Data Analysis}

All experiments were carried out in triplicate. Results were reported as average values with standard deviations. Analysis of variance (ANOVA) and Duncan's multiple range test (DMRT) at $p=0.05$ were used to determine the differences between treatments using SPSS version 12.0.

\section{Results and Discussion}

\subsection{Amylolytic Activities of Rice Cake Starter and Microbiological Characteristic Determination}

Amylolytic properties of microbes in rice cake starter are shown in Figure 1. Results revealed that both rice cake starters contained microbial species with strong amylolytic activity, as evident by the clear zones existing on the starch agar plates after addition of iodine solution. This clear zone was the result of starch degradation by starch-digestion enzymes " $\alpha$-amylase", secreted from microorganisms those presented inside. Molds are suspected to play a dominant role in the degradation of glutinous rice starch into simpler substrate molecules such as soluble dextrin and sugar (Chiang, Chye, \& Mohd Ismail, 2006). Our results demonstrated that amylolytic activities of microbes in the rice cake starters increased with fermentation time. After inoculation and incubation for three days, different characteristics of clear zone between the two rice cake starters were observed (Figure 1). This might be due to the different kinds and amounts of microbes contained inside (Suganthi et al., 2011). Microbiological characteristics also confirmed disparities. In Table 1, no microorganisms were found in the SSK product on day zero while yeast and total plate count were observed in the PTT product. In the following day great changes on microbial counted were observed in both SSK and PTT samples. At the end of fermentation time $\left(3^{\text {rd }}\right.$ day), molds counted in the SSK product reached $1.10 \times 10^{3} \mathrm{cfu} / \mathrm{g}$, yeast $4.00 \times 10^{4} \mathrm{cfu} / \mathrm{g}$ and total plate count $2.96 \times 10^{7} \mathrm{cfu} / \mathrm{g}$, whereas molds counted in the PTT product was $7.00 \times 10^{2} \mathrm{cfu} / \mathrm{g}$, yeast $5.40 \times 10^{5} \mathrm{cfu} / \mathrm{g}$ and total plate count $6.50 \times 10^{7} \mathrm{cfu} / \mathrm{g}$ (Table 1). Our results concurred with Tanasuwapat and Komagata (1995) who reported bacterial count in khao-mak at $1.20 \times 10$ to $4.30 \times 10^{10} \mathrm{cfu} / \mathrm{g}$. Additionally, the dominant mold species isolated from the SSK starter was Amylomyces roxuii while the PTT starter were Amylomyces roxuii and Mucor sp. (data not shown).

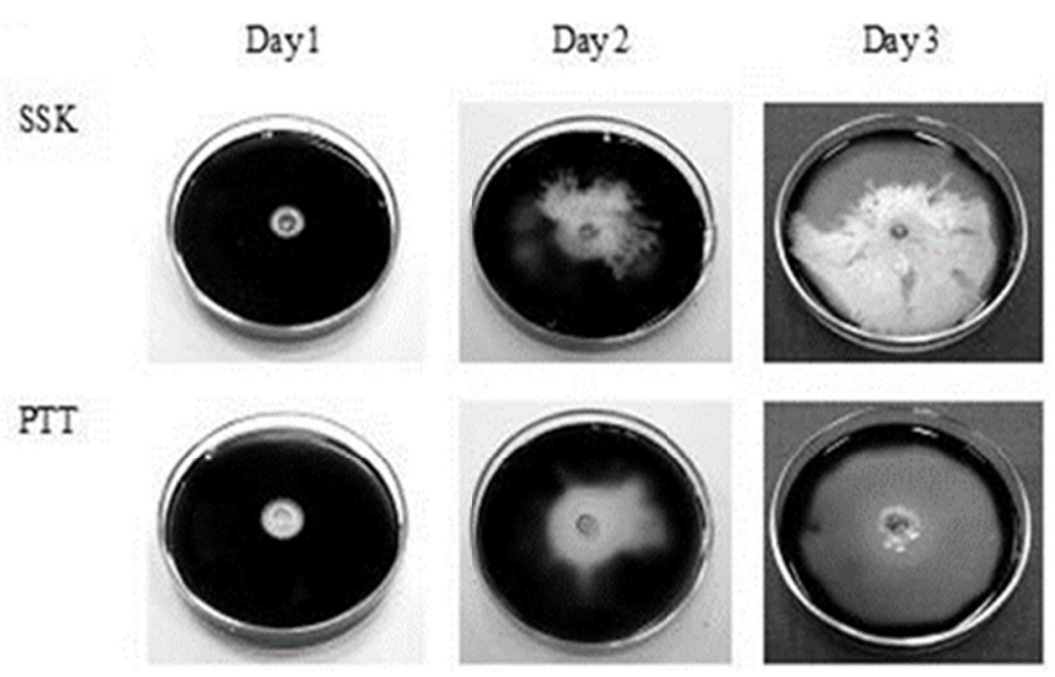

Figure 1. Amylolytic activities of microbes present in starter cultures from the two different sources after iodine solution staining 
Table 1. Microbiological characteristic determination in unfermented cooked glutinous rice (control) and sweet glutinous rice fermented during 3 days

\begin{tabular}{|c|c|c|c|c|c|c|}
\hline \multirow{3}{*}{ Fermentation period (day) } & \multicolumn{6}{|c|}{ Microbial cell $(\mathrm{cfu} / \mathrm{g})$} \\
\hline & \multicolumn{3}{|c|}{ SSK } & \multicolumn{3}{|c|}{ PTT } \\
\hline & mold & yeast & Total plate count & mold & yeast & Total plate count \\
\hline 0 (control) & $<10$ & $<10$ & $<10$ & $<10$ & 12.00 & $4.90 \times 10^{3}$ \\
\hline 1 & $2.30 \times 10^{2}$ & $<10$ & $2.75 \times 10^{7}$ & $3.70 \times 10^{2}$ & $4.40 \times 10^{5}$ & $9.80 \times 10^{4}$ \\
\hline 2 & $3.10 \times 10^{3}$ & 20.00 & $2.50 \times 10^{8}$ & $1.50 \times 10^{3}$ & $4.60 \times 10^{4}$ & $7.30 \times 10^{6}$ \\
\hline 3 & $1.10 \times 10^{3}$ & $4.00 \times 10^{4}$ & $2.96 \times 10^{7}$ & $7.00 \times 10^{2}$ & $5.40 \times 10^{5}$ & $6.50 \times 10^{7}$ \\
\hline
\end{tabular}

\subsection{Chemical Composition}

Chemical compositions of khao-mak samples obtained from the two different sources of traditional starters are shown in Table 2. During fermentation, many simultaneous changes occurred due to microbial activities. Starch molecules in the rice grains were changed to sugars, alcohols and acids. Enzymes produced by the microorganisms present in the starter (Manosroi et al., 2011) had a major effect on the properties of products obtained at different fermentation periods. After $24 \mathrm{~h}$ fermentation, moisture and protein content decreased. As fermentation time lengthened from 1 to 3 days, only slight changes were noted in moisture and protein content. Khao-mak products using SSK and PTT starters showed data with similar trend; however, there were significant differences from the control sample.

Table 2. Moisture, protein, total soluble solids ( ${ }^{\circ} \mathrm{Brix}$ ), $\mathrm{pH}$, total acidity (as lactic acid) and alcohol content in khao-mak using different starter cultures with various fermentation periods

\begin{tabular}{llllllll}
\hline Starter culture & Fermentation time (day) & Moisture (\%) & Protein $(\%)$ & ${ }^{\circ}$ Brix & $\mathrm{pH}$ & Total acidity $(\%)$ & Alcohol (\%) \\
\hline SSK & 0 & $54.28 \pm 0.00 \mathrm{c}$ & $7.66 \pm 0.04 \mathrm{~b}$ & $20.13 \pm 0.23 \mathrm{a}$ & $6.00 \pm 0.03 \mathrm{c}$ & $0.04 \pm 0.00 \mathrm{a}$ & $0.00 \pm 0.00 \mathrm{a}$ \\
& 1 & $51.47 \pm 0.20 \mathrm{~b}$ & $7.30 \pm 0.30 \mathrm{a}$ & $45.20 \pm 0.00 \mathrm{c}$ & $4.48 \pm 0.01 \mathrm{~b}$ & $0.17 \pm 0.01 \mathrm{~b}$ & $0.00 \pm 0.00 \mathrm{a}$ \\
& 2 & $50.66 \pm 0.35 \mathrm{a}$ & $7.31 \pm 0.18 \mathrm{a}$ & $45.60 \pm 0.00 \mathrm{~d}$ & $4.42 \pm 0.00 \mathrm{~b}$ & $0.26 \pm 0.01 \mathrm{c}$ & $1.85 \pm 0.05 \mathrm{~b}$ \\
& 3 & $50.76 \pm 0.17 \mathrm{a}$ & $7.67 \pm 0.03 \mathrm{~b}$ & $44.20 \pm 0.00 \mathrm{~b}$ & $4.27 \pm 0.00 \mathrm{a}$ & $0.31 \pm 0.00 \mathrm{~d}$ & $2.15 \pm 0.13 \mathrm{c}$ \\
\hline $\mathrm{PTT}$ & 0 & $54.28 \pm 0.00 \mathrm{~d}$ & $7.66 \pm 0.04 \mathrm{~b}$ & $20.13 \pm 0.23 \mathrm{a}$ & $6.00 \pm 0.03 \mathrm{c}$ & $0.04 \pm 0.00 \mathrm{a}$ & $0.00 \pm 0.00 \mathrm{a}$ \\
& 1 & $52.40 \pm 0.27 \mathrm{a}$ & $7.38 \pm 0.13 \mathrm{a}$ & $44.20 \pm 0.00 \mathrm{c}$ & $4.18 \pm 0.01 \mathrm{~b}$ & $0.27 \pm 0.01 \mathrm{~b}$ & $0.00 \pm 0.00 \mathrm{a}$ \\
& 2 & $52.69 \pm 0.33 \mathrm{ab}$ & $7.70 \pm 0.04 \mathrm{~b}$ & $44.00 \pm 0.00 \mathrm{c}$ & $3.97 \pm 0.00 \mathrm{a}$ & $0.47 \pm 0.00 \mathrm{c}$ & $2.16 \pm 0.06 \mathrm{~b}$ \\
& 3 & $53.04 \pm 0.14 \mathrm{c}$ & $7.40 \pm 0.23 \mathrm{a}$ & $43.60 \pm 0.00 \mathrm{~b}$ & $4.00 \pm 0.03 \mathrm{~b}$ & $0.50 \pm 0.03 \mathrm{~d}$ & $2.58 \pm 0.08 \mathrm{c}$ \\
\hline
\end{tabular}

Note. Different letters in the same column indicate statistical differences $(p<0.05)$.

Day 0 means unfermented cooked glutinous rice or control.

\subsection{Brix, $p H$ and Total Acidity}

Results in Table 2 also indicated an increase of soluble solids after fermentation due to microbial activities, until reaching a constant of around 44. It can be suggested that damage of rice grain was occurred on the first day fermentation. The $\mathrm{pH}$ was sharply declined after $24 \mathrm{~h}$ fermentation and then changed slightly. The total acidity, on the other hand, was increased over the fermentation time. This result might be due to the correlation between amounts of weak acid and $\mathrm{pH}$ which was factored by the ionic strength of the acid (Gustafsson, Skrifvars, Sandström, \& Waller, 1995). All fermented samples had $\mathrm{pH}$ values lower than 4.5 which concurred with findings in rice wine production (Dung, Rombouts, \& Nout, 2007). In our experiment, the $\mathrm{pH}$ of khao-mak prepared from PTT starter was lower than from SSK. This result agreed well with total acidity (as \%lactic acid), PTT khao-mak contained relatively high lactic acid content. Decrease in $\mathrm{pH}$ with high acidity creates an antimicrobial effect and helps to ensure that fermented food is safe for consumption.

\subsection{Total Sugar, Glucose, Maltose and Alcohol}

Acids and enzymes produced during fermentation were reported to attack the glycosidic linkages of the starch granules (Mestres \& Rouau, 1997), splitting starch molecules into soluble products and continuing the process for various kinds of sugar production (Fennema, 1985; Dung et al., 2007) such as oligosaccharides, disaccharides and mono-saccharides. In our experiment, total sugar and glucose contents of the samples significantly increased 
$(p<0.05)$ with the extension of fermentation period (Table 3). Maltose, in the opposite, sharply increased on the first day and declined thereafter. Some maltose was converted to glucose by acid and enzyme in the system. In the following, alcoholic fermentation occurred wherein sugar commonly glucose was changed to ethanol by the action of yeast presented in the starter (Dung et al., 2007). Moreover, alcohol might be produced by lactic acid bacteria fermentation with the presence of maltose, especially when the fermentation temperature was higher than $30^{\circ} \mathrm{C}$ (Akerberg, Hofvendahl, Zacchi, \& Hahn-Hägerdal, 1998).

Increase of glucose, maltose and total sugar was greater in SSK khao-mak. Sugar contributes to the sweetness and improves the taste and oral texture of the fermented product (Liu, Chen, \& Lin, 2002). Alcohol content sharply increased after 2 days of fermentation and slightly increased by the third day to 2.15 and $2.58 \%$ in khao-mak prepared from SSK and PTT starters, respectively. This demonstrated the ability of microbes in traditional starters, especially yeast, to convert sugar into carbon dioxide and alcohol. In our experiment, microbial activity had more impact on alcohol formation in the PTT starter than in SSK. The presence of alcohol enhanced the acid ability to penetrate the starch granules and caused hydrolysis exclusively inside the granule (Robyt, Choe, Fox, Hahn, \& Fuchs, 1996), and this affected the morphology and properties of fermented grains.

Table 3. Sugar content during khao-mak fermentation using different starter cultures

\begin{tabular}{|c|c|c|c|c|c|c|}
\hline \multirow{2}{*}{ Fermentation day } & \multicolumn{2}{|c|}{ Glucose $(\%)$} & \multicolumn{2}{|c|}{ Maltose $(\%)$} & \multicolumn{2}{|c|}{ Total sugar $(\%)$} \\
\hline & SSK & PTT & SSK & PTT & SSK & PTT \\
\hline 0 & $0.00 \pm 0.00 \mathrm{a}$ & $0.00 \pm 0.00 \mathrm{a}$ & $0.00 \pm 0.00 \mathrm{a}$ & $0.00 \pm 0.00 \mathrm{a}$ & $0.00 \pm 0.00 \mathrm{a}$ & $0.00 \pm 0.00 \mathrm{a}$ \\
\hline 1 & $10.24 \pm 0.08 b$ & $9.42 \pm 0.28 b$ & $5.25 \pm 0.13 \mathrm{c}$ & $5.40 \pm 0.18 \mathrm{~d}$ & $15.49 \pm 0.22 b$ & $14.81 \pm 0.45 b$ \\
\hline 2 & $17.61 \pm 0.13 \mathrm{c}$ & $15.17 \pm 0.32 \mathrm{c}$ & $1.47 \pm 0.07 \mathrm{~b}$ & $2.11 \pm 0.00 \mathrm{c}$ & $19.08 \pm 0.06 \mathrm{c}$ & $17.28 \pm 0.32 \mathrm{c}$ \\
\hline 3 & $19.31 \pm 0.63 d$ & $16.90 \pm 0.09 \mathrm{~d}$ & $1.22 \pm 0.02 b$ & $1.52 \pm 0.05 b$ & $20.52 \pm 0.65 \mathrm{~d}$ & $18.41 \pm 0.14 \mathrm{~d}$ \\
\hline
\end{tabular}

Note. Different letters in the same column indicate statistical differences $(p<0.05)$.

Day 0 means unfermented cooked glutinous rice or control.

\subsection{Morphological Examination}

For ease of morphological comparison, all cooked rice grains, both unfermented and fermented as khao-mak product after 1,2 and 3 days fermentation were freeze-dried and then observed under a scanning electron microscope (SEM). Morphology of the control sample appeared as a smooth surface of gelatinized starch, while the inner grain exhibited a porous gel structure with a dense core (Figure 2). This structural form enhanced the ability of the microflora to attack the grain and provided macro- and micro-environments suitable for its growth. Under SEM examination, all fermented freeze-dried rice grain samples showed dramatic changes on the surface from the first day of fermentation compared with the control. Grains had clearly observable rough and porous surfaces, and the pores noticeably enlarged as fermentation time increased due to exo-corrosion and breakdown of starch granules (Phothiset \& Charoenrein, 2007) by enzymes secreted from microorganisms and by acid generated from fermentation. Moreover, the presence of alcohol in khao-mak affected acid properties by enhancing their ability to penetrate the starch granules, causing the hydrolysis of glycosidic linkages exclusively inside the granules (Ma \& Robyt, 1987; Robyt et al., 1996), produced changes in grain morphological characteristics. In SSK khao-mak, microbial growth on the outer surface of the rice grain was observed after the first day of fermentation, and then penetrating into the core of the grain on the following days. This caused the grain to soften and release sugar, resulting in hollows inside the grain, as evidenced by the flattened structure on the third day. Similar characteristics were observed using the PTT starter but fermented rice grains showed greater damage and were more flattened. This could be the result of enzymatic activity and relatively high acid level produced during fermentation. Morphology of the grains on the third day showed dense microbial growth on the surface, along with tightly packed mycelium inside. 


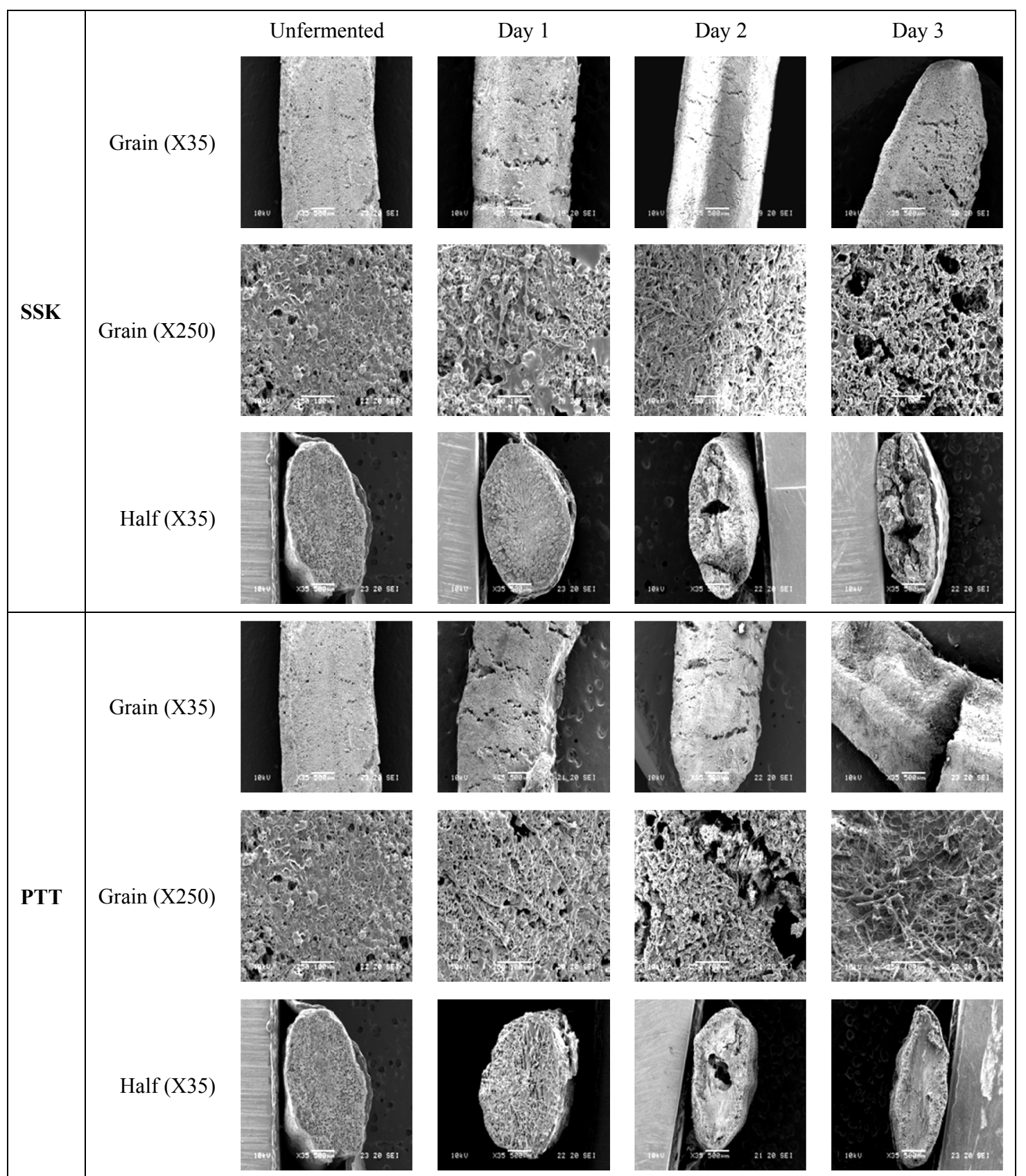

Figure 2. Scanning electron micrographs of unfermented and fermented rice grains (khao-mak) using SSK and PTT starter cultures

\subsection{Pasting Properties}

Pasting properties of control and khao-mak rice flour were significantly different $(\mathrm{p}<0.05)$ (Table 4$)$. Detchew and Naivikul (2005) reported that fermentation influenced flour pasting properties and gelatinization characteristics. Our results also demonstrated that all khao-mak flour had very low peak viscosity, trough, breakdown, final viscosity and setback. The lower paste viscosity was the result of the fermentation process that caused restriction of starch granules in the flour (Phothiset \& Charoenrein, 2007) and also increased breakage stability of the granules (low breakdown). This might be due to changes in starch structure, especially in amorphous regions digested by enzymatic and acidic hydrolysis, thereby leaving the crystalline region. 
Table 4. Pasting properties of rice flour (RVU) obtained from glutinous rice fermented with different traditional starter cultures

\begin{tabular}{lllllll}
\hline Starter culture & Fermentation time (day) & Peak viscosity & Trough & Breakdown & Final viscosity & Setback \\
\hline SSK & 0 & $208.13 \pm 1.83 \mathrm{c}$ & $161.63 \pm 0.29 \mathrm{~d}$ & $46.50 \pm 2.12 \mathrm{~b}$ & $235.50 \pm 6.00 \mathrm{~b}$ & $73.88 \pm 5.72 \mathrm{~b}$ \\
& 1 & $3.08 \pm 0.00 \mathrm{ab}$ & $1.67 \pm 0.00 \mathrm{~b}$ & $1.42 \pm 0.00 \mathrm{a}$ & $2.84 \pm 0.12 \mathrm{a}$ & $1.17 \pm 0.12 \mathrm{~b}$ \\
& 2 & $1.29 \pm 0.06 \mathrm{a}$ & $0.88 \pm 0.06 \mathrm{a}$ & $0.42 \pm 0.00 \mathrm{a}$ & $1.46 \pm 0.06 \mathrm{a}$ & $0.59 \pm 0.12 \mathrm{a}$ \\
& 3 & $5.63 \pm 0.29 \mathrm{~b}$ & $5.25 \pm 0.11 \mathrm{c}$ & $0.38 \pm 0.18 \mathrm{a}$ & $7.75 \pm 0.11 \mathrm{a}$ & $2.50 \pm 0.00 \mathrm{c}$ \\
\hline PTT & 0 & $208.13 \pm 1.83 \mathrm{c}$ & $161.63 \pm 0.29 \mathrm{~d}$ & $46.50 \pm 2.12 \mathrm{~b}$ & $235.50 \pm 6.00 \mathrm{~b}$ & $73.88 \pm 5.72 \mathrm{~b}$ \\
& 1 & $2.30 \pm 0.18 \mathrm{a}$ & $1.25 \pm 0.47 \mathrm{a}$ & $1.04 \pm 0.30 \mathrm{a}$ & $1.88 \pm 0.42 \mathrm{a}$ & $0.63 \pm 0.06 \mathrm{a}$ \\
& 2 & $2.75 \pm 0.00 \mathrm{a}$ & $2.29 \pm 0.06 \mathrm{a}$ & $0.46 \pm 0.06 \mathrm{a}$ & $3.21 \pm 0.06 \mathrm{a}$ & $0.92 \pm 0.00 \mathrm{a}$ \\
& 3 & $7.00 \pm 1.06 \mathrm{~b}$ & $6.38 \pm 0.77 \mathrm{~b}$ & $0.63 \pm 0.29 \mathrm{a}$ & $8.79 \pm 1.00 \mathrm{a}$ & $2.42 \pm 0.23 \mathrm{a}$ \\
\hline
\end{tabular}

Note. Different letters in the same column indicate statistical differences $(p<0.05)$.

Day 0 means unfermented cooked glutinous rice

\subsection{Thermal Properties}

Thermal properties of khao-mak flour were analyzed and results are shown in Table 5. Gelatinization enthalpy of fermented flour samples sharply increased after $24 \mathrm{~h}$ fermentation. Thereafter, rate of increase slightly declined. During the initial stages of fermentation, starch was hydrolyzed by acids and enzymes which quickly degraded the amorphous regions. This led to an increase in crystallinity of the residual starch which caused increase in enthalpy of gelatinization in flour fermented for $24 \mathrm{~h}$. after that hydrolysis rate was slower with less degradation of the crystalline regions, leading to a slight decrease in enthalpy of gelatinization after 2 and 3 days of fermentation. Onset temperature slightly decreased, while the end temperature and temperature range increased, especially in the PTT sample. Our results agreed well with rice flour obtained from rice paper production and acid modified starch (Atichkudomchai, Varavinit, \& Chinachoti, 2002; Phothiset \& Charoenrein, 2007). In this study, gelatinization enthalpy of fermented flour using the SSK starter was higher than when using PTT.

Table 5. Gelatinization properties of unfermented and fermented rice flour obtained from khao-mak at different stages of fermentation using SSK starter culture

\begin{tabular}{lllllllll}
\hline \multirow{2}{*}{ Fermentation day } & \multirow{2}{*}{$\Delta \mathrm{H}(\mathrm{J} / \mathrm{g})$} & \multicolumn{3}{c}{ Peak1 } & & \multicolumn{3}{c}{ Peak2 } \\
\cline { 3 - 4 } \cline { 7 - 8 } & & To $\left({ }^{\circ} \mathrm{C}\right)$ & Tc $\left({ }^{\circ} \mathrm{C}\right)$ & Tc-To $\left({ }^{\circ} \mathrm{C}\right)$ & & To $\left({ }^{\circ} \mathrm{C}\right)$ & Tc $\left({ }^{\circ} \mathrm{C}\right)$ & Tc-To $\left({ }^{\circ} \mathrm{C}\right)$ \\
\hline 0 & $0.07 \pm 0.02 \mathrm{a}$ & $55.92 \pm 0.04 \mathrm{~b}$ & $60.93 \pm 0.08 \mathrm{a}$ & $5.01 \pm 0.12 \mathrm{a}$ & & $81.03 \pm 0.40 \mathrm{~b}$ & $86.19 \pm 0.08 \mathrm{a}$ & $5.15 \pm 0.32 \mathrm{a}$ \\
1 & $1.19 \pm 0.02 \mathrm{~b}$ & $55.36 \pm 0.10 \mathrm{~b}$ & $60.76 \pm 0.03 \mathrm{a}$ & $5.40 \pm 0.13 \mathrm{a}$ & & $77.82 \pm 0.18 \mathrm{a}$ & $86.21 \pm 0.09 \mathrm{a}$ & $8.39 \pm 0.09 \mathrm{~b}$ \\
2 & $1.69 \pm 0.09 \mathrm{c}$ & $55.15 \pm 0.10 \mathrm{~b}$ & $61.14 \pm 0.25 \mathrm{ab}$ & $5.99 \pm 0.15 \mathrm{a}$ & & $77.43 \pm 0.37 \mathrm{a}$ & $87.15 \pm 1.17 \mathrm{a}$ & $9.72 \pm 0.80 \mathrm{bc}$ \\
3 & $1.85 \pm 0.05 \mathrm{c}$ & $53.19 \pm 0.59 \mathrm{a}$ & $61.53 \pm 0.33 \mathrm{~b}$ & $7.62 \pm 0.93 \mathrm{~b}$ & & $77.54 \pm 0.17 \mathrm{a}$ & $87.81 \pm 0.40 \mathrm{a}$ & $10.27 \pm 0.57 \mathrm{c}$ \\
\hline
\end{tabular}

Note. Different letters in the same column indicate statistical differences $(p<0.05)$.

Day 0 means unfermented cooked glutinous rice.

Table 6. Gelatinization properties of unfermented and fermented rice flour obtained from khao-mak at different stages of fermentation using PTT starter culture

\begin{tabular}{lllllllll}
\hline \multirow{2}{*}{ Fermentation day } & \multirow{2}{*}{$\Delta \mathrm{H}(\mathrm{J} / \mathrm{g})$} & \multicolumn{3}{c}{ Peak1 } & & \multicolumn{3}{c}{ Peak2 } \\
\cline { 3 - 5 } \cline { 7 - 8 } & & To $\left({ }^{\circ} \mathrm{C}\right)$ & Tc $\left({ }^{\circ} \mathrm{C}\right)$ & Tc-To $\left({ }^{\circ} \mathrm{C}\right)$ & & To $\left({ }^{\circ} \mathrm{C}\right)$ & Tc $\left({ }^{\circ} \mathrm{C}\right)$ & Tc-To $\left({ }^{\circ} \mathrm{C}\right)$ \\
\hline 0 & $0.07 \pm 0.02 \mathrm{a}$ & $55.92 \pm 0.04 \mathrm{~b}$ & $60.93 \pm 0.08 \mathrm{a}$ & $5.01 \pm 0.12 \mathrm{a}$ & & $81.03 \pm 0.40 \mathrm{~b}$ & $86.19 \pm 0.08 \mathrm{a}$ & $5.15 \pm 0.32 \mathrm{a}$ \\
1 & $1.04 \pm 0.05 \mathrm{~b}$ & $54.93 \pm 0.02 \mathrm{ab}$ & $60.66 \pm 0.16 \mathrm{a}$ & $5.70 \pm 0.04 \mathrm{ab}$ & & $77.48 \pm 0.52 \mathrm{a}$ & $87.19 \pm 0.25 \mathrm{a}$ & $9.17 \pm 0.76 \mathrm{~b}$ \\
2 & $1.13 \pm 0.05 \mathrm{~b}$ & $54.75 \pm 0.61 \mathrm{a}$ & $61.24 \pm 0.24 \mathrm{ab}$ & $6.49 \pm 0.85 \mathrm{bc}$ & & $77.85 \pm 0.25 \mathrm{a}$ & $88.88 \pm 0.25 \mathrm{~b}$ & $11.03 \pm 0.00 \mathrm{~b}$ \\
3 & $1.28 \pm 0.08 \mathrm{c}$ & $54.03 \pm 0.50 \mathrm{a}$ & $61.43 \pm 0.09 \mathrm{c}$ & $7.40 \pm 0.59 \mathrm{c}$ & & $77.92 \pm 0.01 \mathrm{a}$ & $89.09 \pm 0.09 \mathrm{ab}$ & $11.17 \pm 0.88 \mathrm{~b}$ \\
\hline
\end{tabular}

Note. Different letters in the same column indicate statistical differences $(p<0.05)$.

Day 0 means unfermented cooked glutinous rice. 


\section{Conclusions}

It has been concluded that traditional starter culture had the effects on the morphology, chemical and physicochemical properties of the sweet fermented glutinous rice products. Different source of starter culture used for fermentation, demonstrated the products with different qualities such as amount of microbial count, sugar content, titratable acidity as well as alcohol content. Sweet fermented glutinous rice product at $3^{\text {rd }}$ day fermentation using PTT starter culture contained yeast count, acidity and alcohol content higher than SSK. The rice grain morphology showed dramatic changes with numerous pores on rice grain surface and pore's size were enlarged as fermentation time increased. The microbial presence in the starter as well as the fermentation time had an influence on the pasting and thermal properties of the rice flour. Research is underway to obtain a more precise understanding of the changes of rice grain and properties during fermentation that might help to encourage the preservation of this traditional and cultural food. Moreover, it can be apply for further study via using mixed or pure starter cultures to ensure the most desirable and consistency products qualities for in enlarge scale-fermentation process.

\section{Acknowledgements}

This work was financially supported by Japan International Research Center for Agricultural Sciences (JIRCAS), Japan and Institute of Food Research and Product Development, Kasetsart University, Thailand.

\section{References}

Åkerberg, C., Hofvendahl, K., Zacchi, G., \& Hahn-Hägerdal, B. (1998). Modelling the influence of pH, temperature, glucose and lactic acid concentrations on the kinetics of lactic acid production by Lactococcus lactis ssp. lactis ATCC 19435 in whole-wheat flour. Applied Microbiology and Biotechnology, 49, 682-690. https://doi.org/10.1007/s002530051232

AOAC (Association of Official Analytical Chemists). (2006). Official methods of analysis of AOAC International (18th ed.). Arlington, TX.

Atichkudomchai, N., Varavinit, S., \& Chinachoti, P. (2002). Gelatinization transition of acid-modified tapioca starched by differential scanning calorimetry (DSC). Starch/stake, 54, 296-302. https://doi.org/10.1002/ 1521-379X(200207)54:7<296::AID-STAR296>3.0.CO;2-W

BAM (Bacteriological Analytical Manual). (1998). Bacteriological Analytical Manual (8th ed.). Silver Spring, MD.

Campbell-Platt, G. (1994). Fermented foods-A world perspective. Food Research International, 27, 253-257. https://doi.org/10.1016/0963-9969(94)90093-0

Chen, J. J., Lu, S., \& Lii, C. Y. (1999). Effects of milling on the physicochemical characteristics of waxy rice in Taiwan. Cereal Chemistry, 76, 796-799. https://doi.org/10.1094/CCHEM.1999.76.5.796

Chiang, Y. W., Chye, F. Y., \& Mohd Ismail, A. (2006). Microbial diversity and proximate composition of tapai, A Sabah's fermented beverage. Malaysian Journal of Microbiology, 2, 1-6.

De Llanos, R., Querol, A., Pemán, J., Gobernato, M., \& Fernández-Espinar, M. T. (2006). Food and probiotics strains from the Saccharomyces cerevisiae species as a possible origin of human systemic infection. International Journal of Food Microbiology, 110, 286-290. https://doi.org/10.1016/j.ijfoodmicro.2006. 04.023

Detchewa, P., \& Naivikul, O. (2005). Changing of rice properties during Kanomjeen fermentation process. Proceedings of 43rd Kasetsart University Annual Conference: Animals (pp. 387-394). Bangkok, Thailand. Retrieved from http://www.lib.ku.ac.th/KUCONF/KC4306007.pdf

Dung, N. T. P., Rombouts, F. M., \& Nout, M. J. R. (2007). Characteristics of some traditional Vietnamese starch-based rice wine fermentation starters (men). LWT-Food Science and Technology, 40, 130-135. https://doi.org/10.1016/j.lwt.2005.08.004

Fennema, O. R. (1985). Food chemistry. New York: Marcel Dekker.

Gustafsson, T. K., Skrifvars, B. O., Sandström, K. V., \& Waller, K. V. (1995). Modelling of Ph for control. Industrial \& Engineering Chemistry Research, 34, 820-827. https://doi.org/10.1021/ie00042a014

International Approved Methods of Analysis. (2000). Method 60-02.01 Determination of the pasting properties of rice with the rapid visco analyser (10th ed.). St. Paul, MN. 
Laloknam, S., Sirisopana, S., Attaphinyo, P., Poohuarai, S., \& Phornphisutthimas, S. (2009). Detection of amylase activity from fruit and vegetables in an undergraduate classroom. Asian Journal of Food and Agro-Industry, 2, 402-411.

Limtong, S., Sintara, S., Suwanarit, P., \& Lotong, N. (2002). Yeast diversity in Thai traditional fermentation starter (loog-pang). Kasetsart Journal (Nat. Sci.), 36, 149-158.

Liu Y. C., Chen, M. J., \& Lin, C. W. (2002). Studies on lao-chao culture filtrate for a flavoring agent in a yogurt-like product. Asian-Australasian Journal of Animal Science, 15, 602-609. https://doi.org/10.5713/ ajas. 2002.602

Ma, W. P., \& Robyt, J. F. (1987). Preparation and characterization of soluble starches having different molecular sizes and composition, by acid hydrolysis in different alcohols. Carbohydrate Research, 166, $283-297$. https://doi.org/10.1016/0008-6215(87)80064-2

Manosroi, A., Ruksiriwanich, W., Kietthanakorn, B., Manosroi, W., \& Manosroi, J. (2011). Relationship between biological activities and bioactive compounds in the fermented rice sap. Food Research International, 44, 2757-2765. https://doi.org/10.1016/j.foodres.2011.06.010

Mestres, C., \& Rouau, X. (1997). Influence of natural fermentation and drying conditions on the physicochemical characteristics of cassava starch. Journal of the Science of Food and Agriculture, 74, 147-155. https://doi.org/10.1002/(SICI)1097-0010(199706)74:2<147::AID-JSFA781>3.0.CO;2-J

Phothiset, S., \& Charoenrein, S. (2007). Morphology and physicochemical changes in rice flour during rice paper production. Food Research International, 40, 266-272. https://doi.org/10.1016/j.foodres.2006.06.002

Robyt, J. F., Choe, J. Y., Fox, J. D., Hahn, R. S., \& Fuchs, E. B. (1996). Acid modification of starch granules in alcohols: reactions in mixtures of two alcohols combined in different ratios. Carbohydrate Research, 283, 141-150. https://doi.org/10.1016/0008-6215(96)00007-9

Suganthi, R., Benazir, J. F., Santhi, R., Ramesh Kumar, V., Hari A., Meenakshi N, ... Lakshmi, R. (2011). Amylase production by Aspergillus Niger under solid state fermentation using agro-industrial wastes. International Journal of Engineering Science and Technology, 3, 1756-1763.

Tanasupawat, S., \& Komagata, K. (1995). Lactic acid bacteria in fermented foods in Thailand. World Journal of Microbiology and Biotechnology, 11, 253-256. https://doi.org/10.1007/BF00367094

Tochampa, W., Jittrepotch, N., Kongbangkerd, T., Kraboun, K., \& Rojsuntornkitti, K. (2011). The study of microwave heating time on chemical and microbiological properties and sensory evaluation in sweet fermented glutinous rice (Khao-Mark). International Food Research Journal, 18, 239-248.

Tongyai, A., Riebroy, S., Maneerat, S., Siriwong, N., \& Chulakarungka, S. (2012). Changes in physicochemical and sensory characteristics during fermentation of Khaow-Maak from black glutinous rice. Proceedings of the 50th Kasetsart University Annual Conference. Bangkok, Thailand.

Wang, H. L., \& Hesseltine, C. W. (1970). Sufu and lao-chao. Journal of Agricultural and Food Chemistry, 18, 572-575. https://doi.org/10.1021/jf60170a046

Wongpiyachon, S. (1995). Utilization of rice for rice wine and blended whisky (Unpublished Master's thesis, Kasetsart University, Bangkok, Thailand).

\section{Copyrights}

Copyright for this article is retained by the author(s), with first publication rights granted to the journal.

This is an open-access article distributed under the terms and conditions of the Creative Commons Attribution license (http://creativecommons.org/licenses/by/4.0/). 